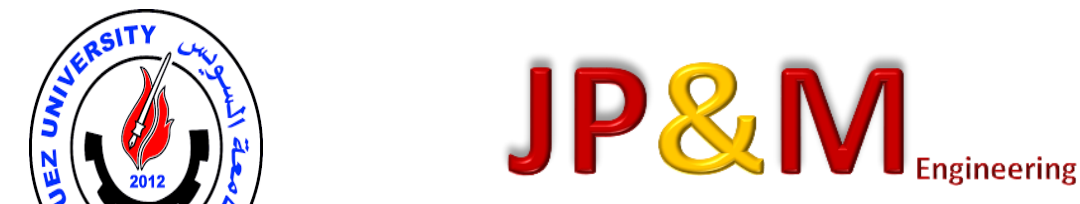

Journal of Petroleum and Mining Engineering

\title{
Oil Characteristics and Source Rock Potential of Abu Rudeis-Abu Zenima Area, Central Province, Gulf of Suez, Egypt
}

Elmaadawy, K. G.

Geology Department, Faculty of Science, Menoufia University

*Corresponding author e-mail: kelmaadawy@yahoo.com

\section{Article Info \\ Received 11 may. 2021 Revised 02 Jun. 2021 Accepted 05 Jun. 2021}

\section{Keywords}

Oil characteristics; Source rock potential; Abu RudeisAbu Zenima area; Gulf of Suez

\begin{abstract}
The Gulf of Suez region is one of the most important petroleum provinces in Egypt and the Abu Rudeis-Abu Zenima area (ARAZ) located in the central province of the Suez Gulf on the eastern side. The scope of the current work is to evaluate the oils in the ARAZ area to identify oils characteristics and source rock potential using the data of whole oil gas chromatography and gas chromatography-mass spectrometry (GC-MS), in addition to stable carbon isotope analysis and vanadium and nickel contents. The bulk oils composition in ARAZ area characterized by moderate saturates and aromatics contents, high sulfur and NSO \&asphaltene contents and heavy and normal API gravity. The composition of oils differs primarily due to their degree of thermal maturity. The oils generated from algal marine material with little terrestrial materials deposited under anoxic depositional conditions suggested by a low Pristane/Phytane ( $\mathrm{Pr} / \mathrm{Ph}$ ) ratio. Moreover, the oils generated from carbonate source rocks of Thebes and Duwi rock units indicated by high $\mathrm{C}_{31}-\mathrm{C}_{35}$ Hopanes $(45-50 \%)$ and $C_{35} / C_{34}$ extended Hopane ratio $(0.99-1.12)$. The oils reached the peak-oil generation stage $(0.85 \% \mathrm{Ro})$ indicated by the sterane isomerization ratio (20S \% $\mathrm{C}_{29}$ ) that is less than $55 \%$. The oils of ARAZ area are matched the oils of the Gulf of Suez.
\end{abstract}

\section{Introduction}

Abu Rudeis-Abu Zenima area (ARAZ) is located in the central province of the Gulf of Suez on the eastern side. October Field and Ras Budran Field surrounded the ARAZ from the west and north directions respectively (Fig.1).

Many authors studied the characteristics of oils and source rocks in the Gulf of Suez and they concluded that the source rocks of Duwi and Thebes formations characterized by good to excellent organic content and kerogen of type II and mixed II/III with maturity ranging from immature to peak oil window (\%Ro < 0.9) based on the analyzed pyrolysis data. Based on the carbon isotopes of biomarker data, the source rocks deposited under anoxic conditions with mainly marine organic matter and minor terrigenous higher plants. The chemical composition of the Gulf oils are variable in API gravity and sulfur contents mainly due to different thermal maturity levels (Alsharhan and Salah 1997 [1]; Wever, 1999 [2], 2000 [3]; Alsharhan 2003 [4]; Younes and Philip, 2005 [5]; El Nady and Mohamed, 2016 [6]; Mohamed and El Nady, 2016 [7]; El Nady et al., 2016 [8]; Younes et al, 2017 [9]; Mohamed and El Nady, 2019 [10]; El Diasty et al., 2020 [11], Elmaadawy et al, 2021 [12]).

Little published works studied the oil characteristics and source rock potential of the Abu Rudeis-Abu Zenima (ARAZ), therefore, the current work aims to assess the oils of selected wells in the ARAZ area to recognize the oil characteristics, organic matter types, depositional environments and source rocks potential. Moreover, study the impact of the oils geochemistry on the hydrocarbon migration and entrapment and determining if the oils geochemistry in the ARAZ area consistent or not with the oils of the Gulf of Suez basin.

\section{Geological and tectonic setting}

The interplay of Arabian and African plates during Late Oligocene - Early Eocene resulted in the Suez rift in Northwest-southeast direction (Garfunkel and Bartov 1977 [13]). Large-scale zones of normal faults surrounded both margins of the Suez rift and the rift subdivided into three main tectonic domains attributed to the polarity changing of the block faults (Patton et al. 1994 [14]; Moustafa, 1996 [15]; Younes and McClay 2002 [16]). Three main basins of northern Darag, central Belayim and southern Amal-Ziet recognized with a Zaafarana accommodation zone between northern and central basins and a Morgan accommodation zone between central and southern basins (Colletta et al. 1988 [17]).These accommodations resulted from half grabens and horsts related to large-scale normal faults (Bosworth 1995[18], 2015 [19]; Bosworth and Durocher 2017 [20]).

Lithostratigraphically, the Suez rift basin encompasses pre rift, syn rift and post rift major sedimentary sequences (Patton et al. 1994 [14]; Bosworth et al. 1998 [21]; Khalil and McClay 2001 [22]) (Fig. 2) and Peijs et al (2012) [23] classified the 


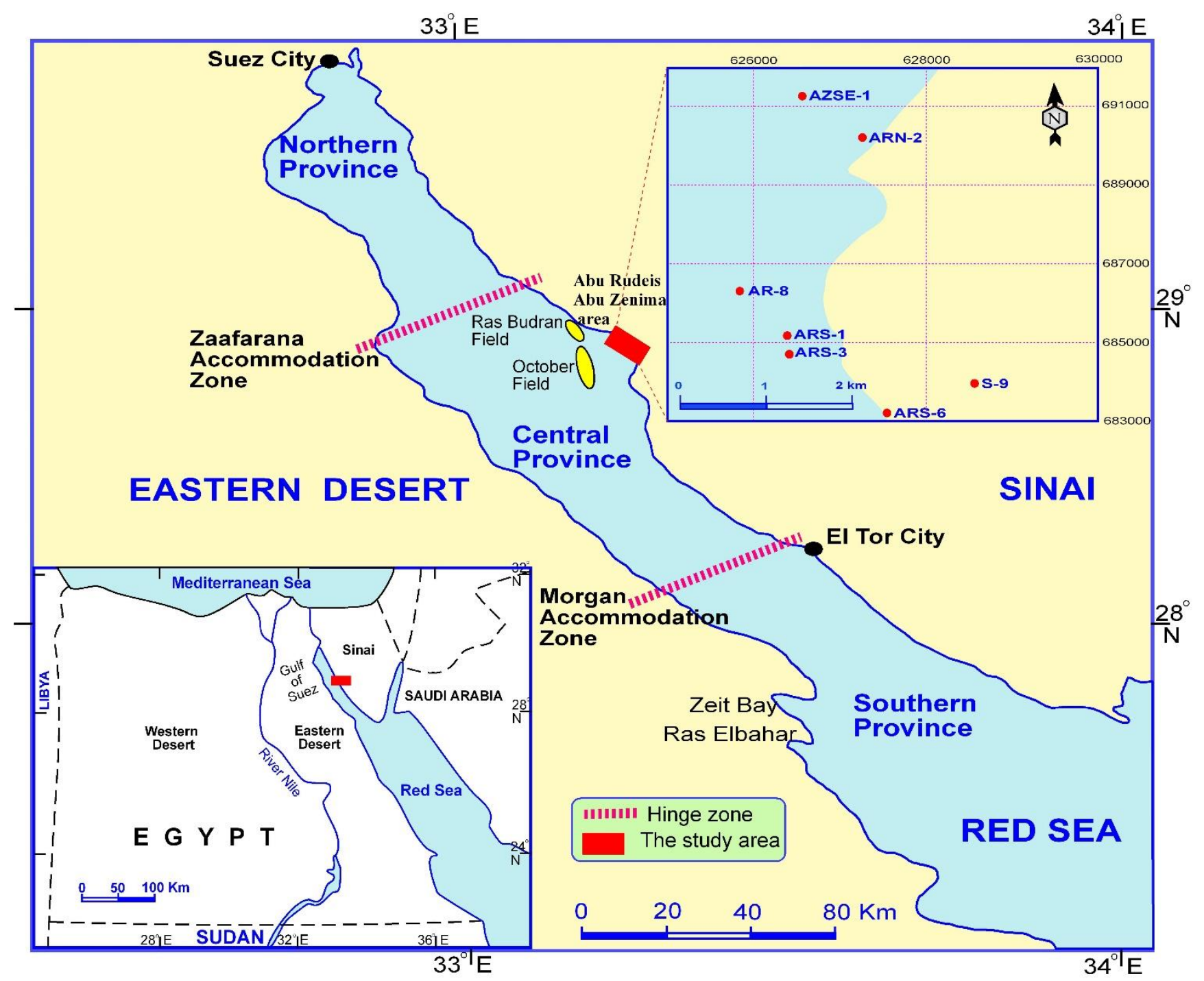

Figure 1 Location map of the Gulf of Suez and the well location map of Abu Rudeis-Abu Zenima area of the studied wells.

sedimentary cover into five major tectonosedimentary sequences. The pre-rift succession bottomed with shallow marine to fluvial clastics of Nubia sandstones with age extending from Cambrian to Early Cretaceous. In subsurface, the Nubia Formation classified into units of A, B, C and D (Klitzsch and Squyres, 1990 [24]; Klitzsch, 1990 [25]). These unites are cross-bedded sandstones with shale interbeds (Darwish and El-Araby, 1993 [26]; Khalil and McClay 2001[22]). An unconformity surface separates the Nubia Formation from the overlying Cretaceous deposits of Raha, Wata, Matulla, Duwi and Sudr formations with an age extending from Cenomanian to Maastrichtian composed of marine siliciclastics and carbonate deposits (EGPC, 1964 [27]; Issawi, 1973 [28]; Webster, 1982 [29]; Sellwood and Netherwood, 1984 [30]; Alsharhan, 2003 [4]). The Paleocene represented by the Esna Formation composed of shale deposits and Eocene represented by the Thebes and Mokattam formations composed of carbonate deposits (McClay et al. 1998 [31]). The syn-rift succession represented by seven formations of Abu Zenima, Nukhul, Rudeis, Kareem, Belayim, South Gharib and Zeit with age extending from Early Miocene (Aquitanian) to Late Miocene Messinian. The lithology of the syn-rift deposits varies from carbonates (Abu Zenima) to sandstones (Nukhul, Upper South Gharib and Zeit) and evaporites (Belayim and Lower South Gharib) and shale (Rudeis and Kareem) (Scott and Govean, 1985 [32]; Smale et al., 1988 [33]; Rouchy et al., 1995 [34]; Richardson and Arthur, 1988 [35]; Rohais et al., 2016 [36]).

The pre Miocene source rocks of Duwi and Thebes formations have average TOC contents of 3.63 wt\% and 3.28 wt\% respectively suggesting very good to excellent potential and favorable conditions for the organic matter preservation during Late Cretaceous Campanian and Late Eocene times (Robinson and Engel 1993[37]; El Diasty et al. 2014 [38]; El-Shafeiy et al. 2017 [39]).

\section{Dataset and methodology}

\section{Geochemical and biomarker data}

Seven oils from different reservoir intervals analyzed by the whole oil gas chromatography and gas chromatography-mass spectrometry (GC-MS). The geochemical data of six wells of AZSE-1, ARN-2, AR-8, ARS-1, ARS-3 and S-9. The oils came from different reservoir intervals at different elevations such NubiaA, Matulla, Thebes and Nukhul reservoirs (Table 1). 


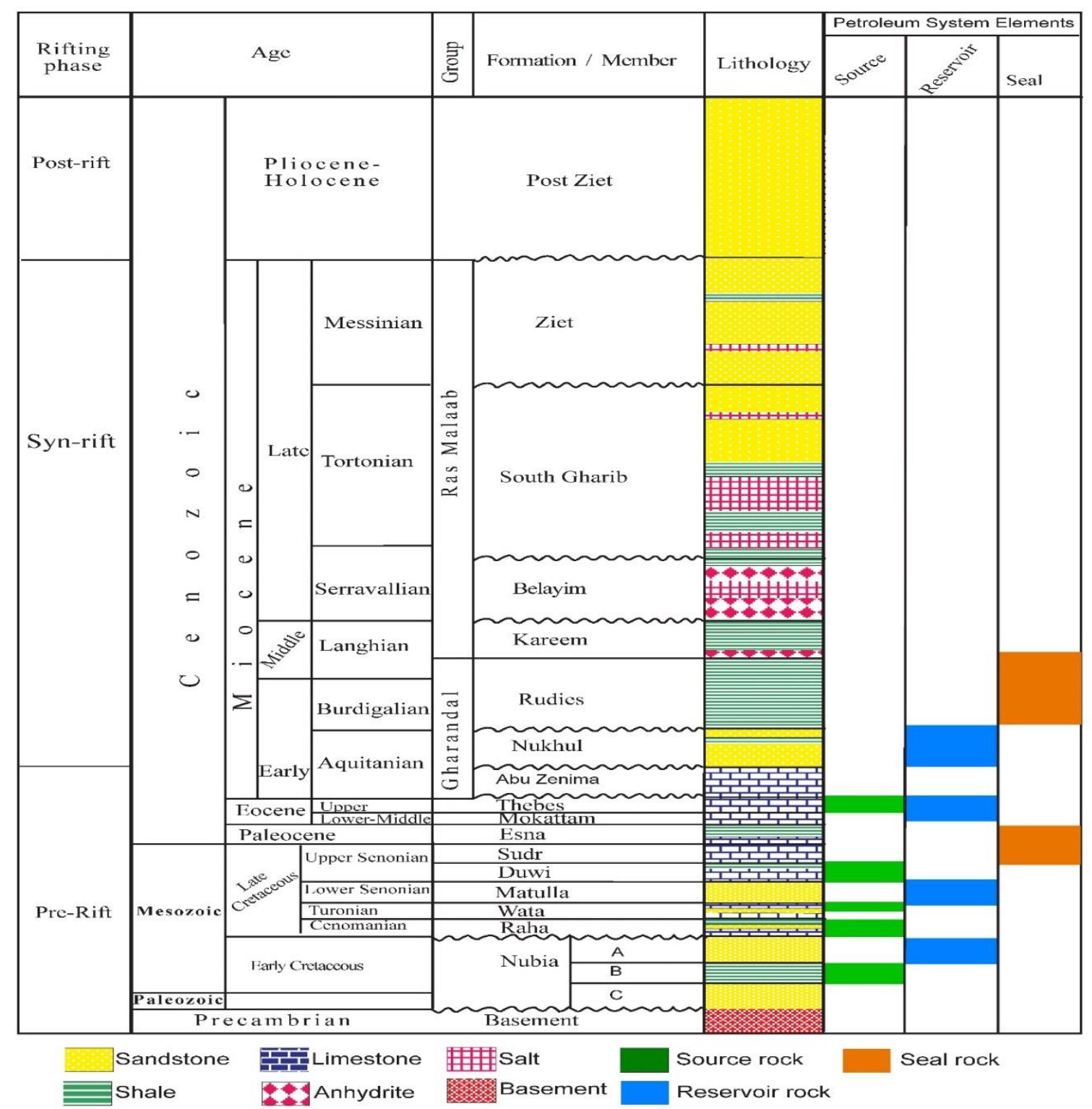

Figure 2 Lithostratigraphic column of the study area based on the available studied wells.

Table 1. Wells of oil samples and their reservoir intervals.

\begin{tabular}{|l|l|c|c|c|}
\hline No. & \multicolumn{1}{|c|}{ Well } & Label & Reservoir & Depth intervals (m) \\
\hline $\mathbf{1}$ & Abu Rudeis-8 & AR-8 & Nukhul & $2519-2647$ \\
\hline $\mathbf{2}$ & Abu Rudeis S-3 & ARS-3 & Nubia-A & $3391-3395$ \\
\hline $\mathbf{3}$ & Abu Zenima SE-1 & AZSE-1 & Matulla & $3753-3770$ \\
\hline $\mathbf{4}$ & Abu Rudeis S-1 & ARS-1 & Matulla & $3177-3198$ \\
\hline $\mathbf{5}$ & Abu Rudeis N-2 & ARN-2 & Matulla & $3787-3838$ \\
\hline $\mathbf{7}$ & Sidri-9 & S-9 & Matulla & $3492-3606$ \\
\hline
\end{tabular}

The data of bulk oil composition include saturates \% and aromatics \%, NSO \% compounds, asphaltene \%, API gravity and sulphur $\%$ content (Table 2 ). Whole oil gas chromatography data of Normal alkane distribution ( $\mathrm{n}-\mathrm{C} 18-\mathrm{C} 38$ ), Pristane/Phytane ( $\mathrm{Pr} / \mathrm{Ph}$ ) ratio and $\mathrm{C7}$-derived expulsion temperature. GC-MS

\section{Rock-Eval pyrolysis data}

Rock-Eval pyrolysis data such S1, S2, S3, Tmax, hydrogen index $(\mathrm{HI})$, oxygen index $(\mathrm{OI})$, production index $(\mathrm{PI})$, total organic carbon (TOC \%) and vitrinite data comprise triterpenes $(\mathrm{m} / \mathrm{z} 191)$ and steranes $(\mathrm{m} / \mathrm{z}$ 217) distributions, biomarker isomerization, organic facies and depositional environment ratios (Tables 3 \& 4). In addition to stable carbon isotope analysis of saturate and aromatic fractions with vanadium and nickel contents for well Sidri-9 (Fig.3).

reflectance (Ro \%), for the pre-Miocene source rocks (Table 5). 
Table 2. Bulk composition data for the studied wells.

\begin{tabular}{|l|c|c|c|c|c|c|}
\hline Well & AR-8 & ARS-3 & AZSE-1 & ARS-1 & ARN-2 & S-9 \\
\hline API Gravity & 19.3 & 17.3 & 25.3 & 21.1 & 12.8 & 16.81 \\
\hline Sulfur wt. \% & 2.5 & 3.7 & 2.8 & 3.5 & 1.4 & 2.54 \\
\hline Saturates \% & 54.8 & 45.8 & 44.1 & 44.2 & 42.1 & 36.9 \\
\hline Aromatics \% & 20.7 & 28 & 24.7 & 27.6 & 22.8 & 25.8 \\
\hline NSO \% & 11.2 & 8.9 & 8.1 & 9.1 & $10 / 2$ & 12.3 \\
\hline Asphaltene \% & 13.3 & 17.3 & 23.1 & 19.1 & 24.9 & 25 \\
\hline Pr/Ph & 0.73 & 0.69 & 0.73 & 0.71 & 0.66 & 0.68 \\
\hline Pr/n-C17 & 0.56 & 0.68 & 0,59 & 0.60 & 0.54 & 0.62 \\
\hline Ph/n-18 & 0.79 & 1.03 & 0.89 & 0.93 & 0.87 & 0.93 \\
\hline
\end{tabular}

Table 3. Biomarker and maturity dependent ratios.

\begin{tabular}{|c|c|c|c|c|c|c|}
\hline Well & AR-8 & ARS-3 & AZSE-1 & ARS-1 & ARN-2 & S-9 \\
\hline$\% 20 \mathrm{~S} \mathrm{C}_{29}$ Steranes & 52.80 & $51 / 30$ & 54.64 & 51.20 & 51.60 & 49.4 \\
\hline$\% \alpha \beta \beta C_{29}$ Steranes & 57.10 & 55.20 & 54.82 & 55.20 & 54.80 & 53.6 \\
\hline$\% 22 \mathrm{~S} \mathrm{C}_{31}$ Hopane & 59.80 & $60 / 00$ & 56.93 & 59.80 & 59.10 & 58.6 \\
\hline$\% 22 \mathrm{~S} \mathrm{C}_{32}$ Hopane & 60.80 & 60.30 & 58.02 & 60.50 & 60.30 & 60.4 \\
\hline $\mathrm{Tm} / \mathrm{Ts}$ & 3.43 & 4.36 & 4.30 & 4.30 & 4.25 & - \\
\hline$C_{29}$ Neohopane/ $C_{29}$ Norhopane & 0.11 & 0.11 & - & 0.10 & 0.10 & 0.10 \\
\hline \% short chain steranes & 10.20 & 6.70 & - & 7.60 & 8.80 & 8.7 \\
\hline
\end{tabular}

Table 4. Organic facies and depositional environment ratios

\begin{tabular}{|c|c|c|c|c|c|c|}
\hline Well & AR-8 & ARS-3 & AZSE-1 & ARS-1 & ARN-2 & S-9 \\
\hline $\mathrm{C}_{19}+\mathrm{C}_{20}$ tricyclic / $\mathrm{C}_{23}$ tricyclic & 0.27 & 0.21 & 0.25 & 0.20 & 0.23 & 0.25 \\
\hline $\mathrm{C}_{23}$ tricyclic / $\mathrm{C}_{24}$ tetracyclic & 3.90 & 4.48 & 3.99 & 4.40 & 3.67 & \\
\hline $\mathrm{C}_{24}$ tetracyclic / $\mathrm{C}_{26}$ tricyclic & 0.68 & 0.58 & 0.69 & 0.59 & 0.68 & 0.69 \\
\hline$C_{25}$ tricyclic / $C_{26}$ tricyclic & 1.25 & 1.28 & 1.40 & 1.26 & 1.24 & 1.22 \\
\hline $\mathrm{C}_{29}$ Norhopane / $\mathrm{C}_{30}$ Hopane & 0.89 & 0.75 & 0.88 & 0.81 & 0.87 & 0.78 \\
\hline$C_{30}$ Oleanane / $C_{30}$ Hopane & 0.05 & 0.03 & 0.03 & 0.04 & 0.03 & 0.03 \\
\hline Gammacerane / $\mathrm{C}_{30}$ Hopane & 0.09 & 0.11 & 0.11 & 0.12 & 0.11 & 0.11 \\
\hline Extended Hopanes & 29.37 & 37.69 & 32.72 & 34.84 & 34.73 & \\
\hline $\mathrm{C}_{35} / \mathrm{C}_{34}$ Extended Hopanes & 0.99 & 1.12 & 1.09 & 1.09 & $1 / 06$ & 1.41 \\
\hline Tricyclic Terpanes / Hopanes & 0.50 & 0.35 & 0.48 & 0.40 & 0.39 & - \\
\hline Hopanes / Steranes & 1.50 & 1.79 & 3.13 & 2.17 & 2.73 & 2.62 \\
\hline $\mathrm{C}_{27} \alpha \alpha \alpha 20 \mathrm{R} / \mathrm{C}_{29} \alpha \alpha \alpha 20 \mathrm{R}$ & 1.32 & 1.34 & 1.81 & 1.19 & 1.40 & - \\
\hline
\end{tabular}

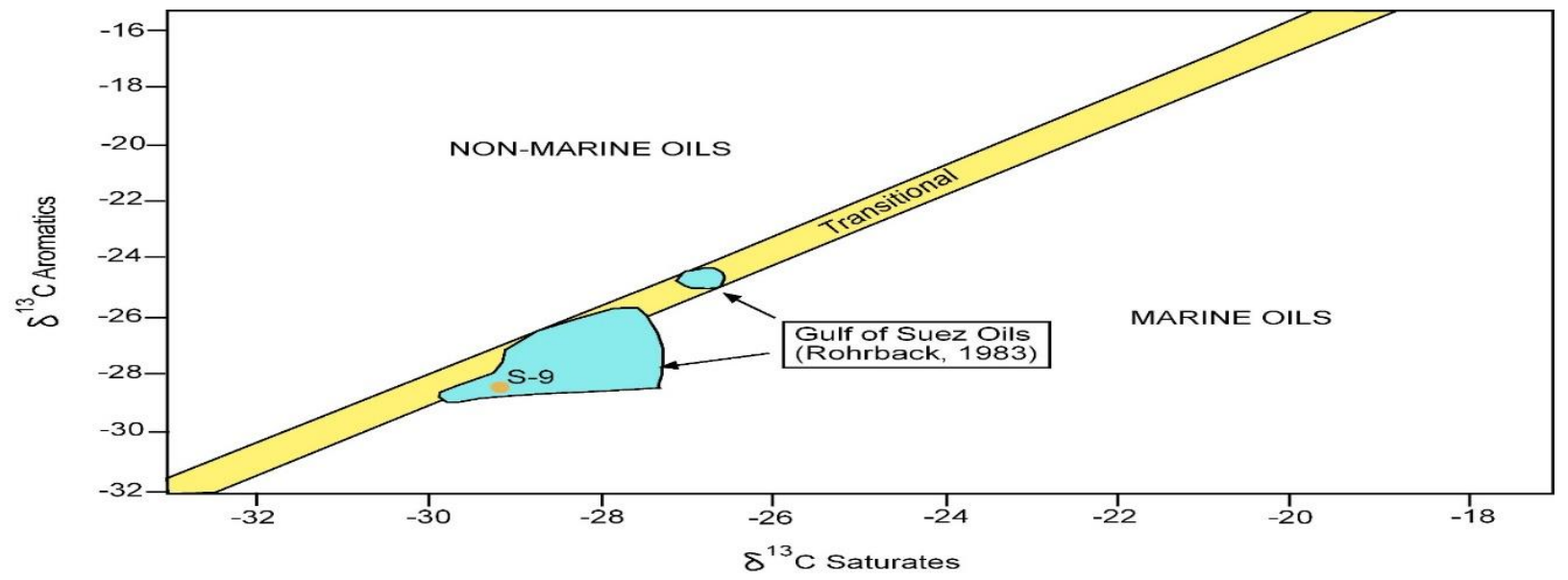

Figure 3. Carbon isotope compositions of aromatics versus saturates for Sidri-9 well (Modified after Sofer, 1984 [44]). 
Table 5. Average maturity parameters for the pre-Miocene source rocks in Rudeis Field (Mostafa, 1993).

\begin{tabular}{|l|c|c|c|c|c|c|c|c|}
\hline Source rocks & TOC\% & S1 & S2 & S3 & Tmax & HI & OI & PI \\
\hline Sudr & 0.68 & - & 2.7 & - & - & 397 & - & - \\
\hline Duwi & 3.2 & 5.07 & 4.5 & - & - & - & - & 0.53 \\
\hline Matulla & 2.52 & 1.7 & 17.6 & 0.34 & 422 & 698 & 13.5 & 0.09 \\
\hline
\end{tabular}

\section{Results and Discussion}

\section{Oils characterization}

Whole oil gas chromatograms (Fig. 4) show that the light hydrocarbon composition of oils indicates a high n-Heptane (1.5-2.1) attributed to water washing or maturation based on the plot of heptane versus isoheptane indices of Thomson (1987 [40] ) (Fig.5 a) and the shallow oil of AR- 8 well is less affected (1.2) than those of the deep oils. The bulk composition of the most oils characterized by a medium saturates and aromatics (54.7-73.8 wt \%), relatively high NSO \&asphaltene contents (24.5 -35.1 wt \%) (Fig.5 b), a heavy API gravity (API $>12.8^{\circ}$ and $<25.3^{\circ}$ ) and a relatively high sulfur content (1.4-3.7 wt \%) (Table 2). In contrast, AR-8 well marked by the highest saturate/aromatics ratio (2.6) and the lowest NSO \& asphaltene contents ( $24.5 \mathrm{wt} \%)$. In addition, the two oils of wells ARS-3 and ARS-1 have lower NSO \& asphaltene contents (26.2-28.2 wt \%) than those of AZSE-1 and ARN-2 (31.2-35.1 wt \%)-suggesting minor compositional differences among the oils in the ARAZ area.

The variations in bulk oils composition not primarily related to the API gravity and sulfur contents. However, the oils of wells ARS- 1 and ARS-3 characterized by the highest sulfur content (3.5-3.7\%) are relatively heavier than the other oils and have medium NSO and Asphaltene contents, whereas the oil of AZSE-1 well has a high API gravity content $\left(25.3^{\circ}\right)$. The oil of well ARN-2 has the lowest contents of API gravity content $\left(12.8^{\circ}\right)$ and sulfur content (1.4 $\%)$, while the oil of AZSE- 1 well has the highest API value $\left(25.3^{\circ}\right)$ with a relatively high sulfur content (2.9\%). The oil of AR-8 well has moderate contents of sulfur (2.5\%) and API $\left(21.1^{\circ}\right)$, while the rest of oils have low NSO \& asphaltene contents and a high saturate-aromatics ratio.

The results of the bulk oils composition in ARAZ area matched the results of the Gulf of Suez in that the API gravity values vary from heavy to moderate and are inversely proportional to the sulfur contents. The API increases from north to south attributed to the increasing of thermal maturity of the source rocks in the same direction (Clark and Philp 1989 [41]; Subroto et al. 1991 [42]; Alsharhan and Salah 1997 [43]; Alsharhan 2003 [4], El Diasty et al., 2020 [11]).

Stable carbon isotopes for saturates and aromatics range between (30.20-24.50) and (29.40 -22.60) respectively, which indicate that the oils of the Gulf of Suez mainly generated from marine organic materials with minor terrestrial contribution (Sofer, 1984 [44]; Collister and Wavrek 1996 [45]; El Diasty et al. 2020 [11]). In ARAZ area, the stable carbon isotopes for saturates and aromatics are 29.2 and 28.7 respectively for well S-9 suggesting good correlation with the Gulf of oils (Fig.3).

\section{Terpanes and Steranes distributions}

The biomarker ratios attributed to terpanes and steranes are important in identifying the organic matter origins, depositional conditions, thermal maturity level and the age of the source rock (Hunt 1996 [46]; Peters et al. 2005 [47]). The terpanes (m / $z$ 191) distribution suggests the oils mainly derived from algal organic matter and from minor terrestrial organic matter that indicated by the low C19 tricyclic / C23 tricyclic terpanes, high hopane and high C23 tricyclic / C24 tetracyclic terpane (Fig. 6). Moreover, the source rocks deposited under anoxic conditions indicated by high C35 homohopane.

The sterane ( $\mathrm{m} / \mathrm{z}$ 217) distribution suggests the organic matter mainly are algal with little amounts of terrestrial indicated by high C27 $\alpha \alpha \alpha$ (20R) / C29 $\alpha \alpha \alpha$ (20R) sterane, C27, C28 \& C29 $\alpha \alpha \alpha$ (20R) sterane and C27, C28 \& C29 regular sterane (Fig.7). The oils derived from Kerogen type II with the organic matter of bacterial-algal with minor terrigenous organic matter.

\section{Maturity related biomarker ratios}

The chromatograms of the whole oil-gas show a normal alkane distribution in the range of $n-C 10$ to $n-$ C38 except the AR-8 oil of shallow reservoir indicating a slightly higher maturity than that of deeper reservoirs. Thebes and Duwi source rocks characterized by low $\mathrm{Pr} / \mathrm{Ph}$ ratio indicating algal and terrigenous organic matter deposited under reducing conditions (Mostafa, 1993 [48]). In ARAZ area, the Pristane/Phytane ( $\mathrm{Pr} / \mathrm{Ph}$ ) ratio is low and ranging between 0.66 and 0.73 in wells $A R N-2$ and AR- 8 respectively suggesting a marine organic material deposited under moderate reducing depositional conditions (Fig. 8). $\mathrm{Pr} / \mathrm{n}-\mathrm{C} 17$ and $\mathrm{Ph} / \mathrm{n}-\mathrm{C} 18$ ratios are useful in recognizing organic material types, maturity level and biodegradation (Connan and Cassou 1980 [49]; Peters et al. 1999 [50]).The oils were come from nearly the same origin of marine organic material suggested by small variations in $\mathrm{Pr} / \mathrm{Ph}, \mathrm{Pr} / \mathrm{n}-\mathrm{C} 17$ and $\mathrm{Ph} / \mathrm{n}-\mathrm{C} 18$ ratios. These oils have low moderate maturity (Ro $\leq 0.8 \%$ ) suggesting by low $\mathrm{Pr} / \mathrm{n}-\mathrm{C} 17$ (0.5) and $\mathrm{Ph} / \mathrm{n}$ - $\mathrm{C} 18$ (0.9) values, in addition to low ranging between 110 and $115{ }^{\circ} \mathrm{C}$ and AR- 8 oil has the lowest C7-derived expulsion temperature of $103{ }^{\circ} \mathrm{C}$ (Fig.9). 

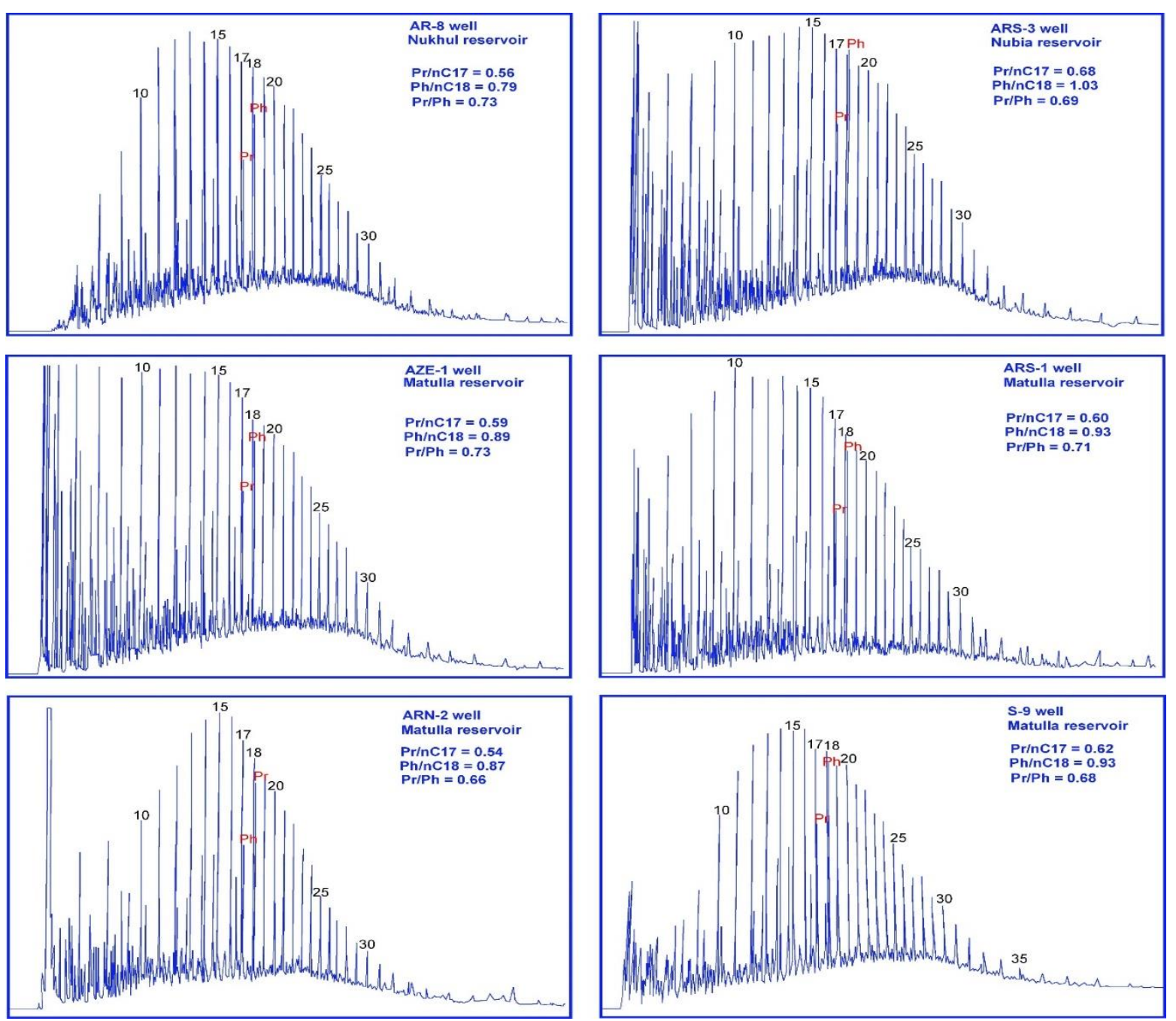

Figure 4 Whole oil gas chromatograms in ARAZ area.

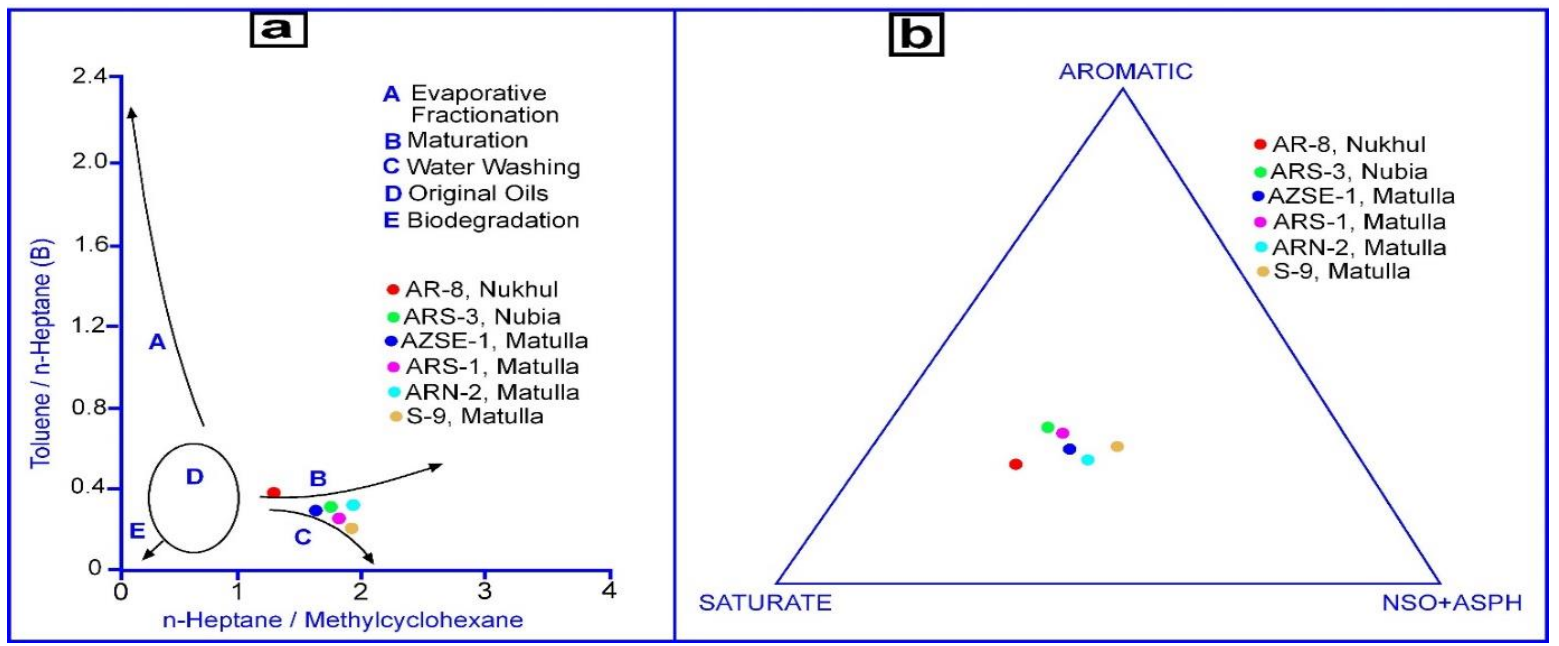

Figure 5 Thomson alteration plot for heptane versus isoheptane (a) and bulk oil composition (b).

The $20 \mathrm{~S} \% \mathrm{C}_{29}$ sterane isomerization ratio as a maturity indicator is lower than $55 \%$ indicating that the oils reach approximately to the peak oil generation stage (0.85\% Ro), which consistent to the maturity derived from $C_{7}$ (0.7-0.8 $\%$ Ro).

Trace elements Vanadium and nickel contents in in well S-9 oils are 96.4 ppm and 41.5 and the Vanadium / nickel ratio is 2.32 . These results suggest different source rocks with different thermal maturity levels for oils (Moldowan et al. 1986 [51]; Hunt 1996 [46]; El Diasty and Peters 2014 [38]).

\section{Organic facies and depositional environment}

GC-MS biomarker parameters for oils of the ARAZ area indicate organic facies, thermal maturity and alteration degree (tables 3 \&4). 

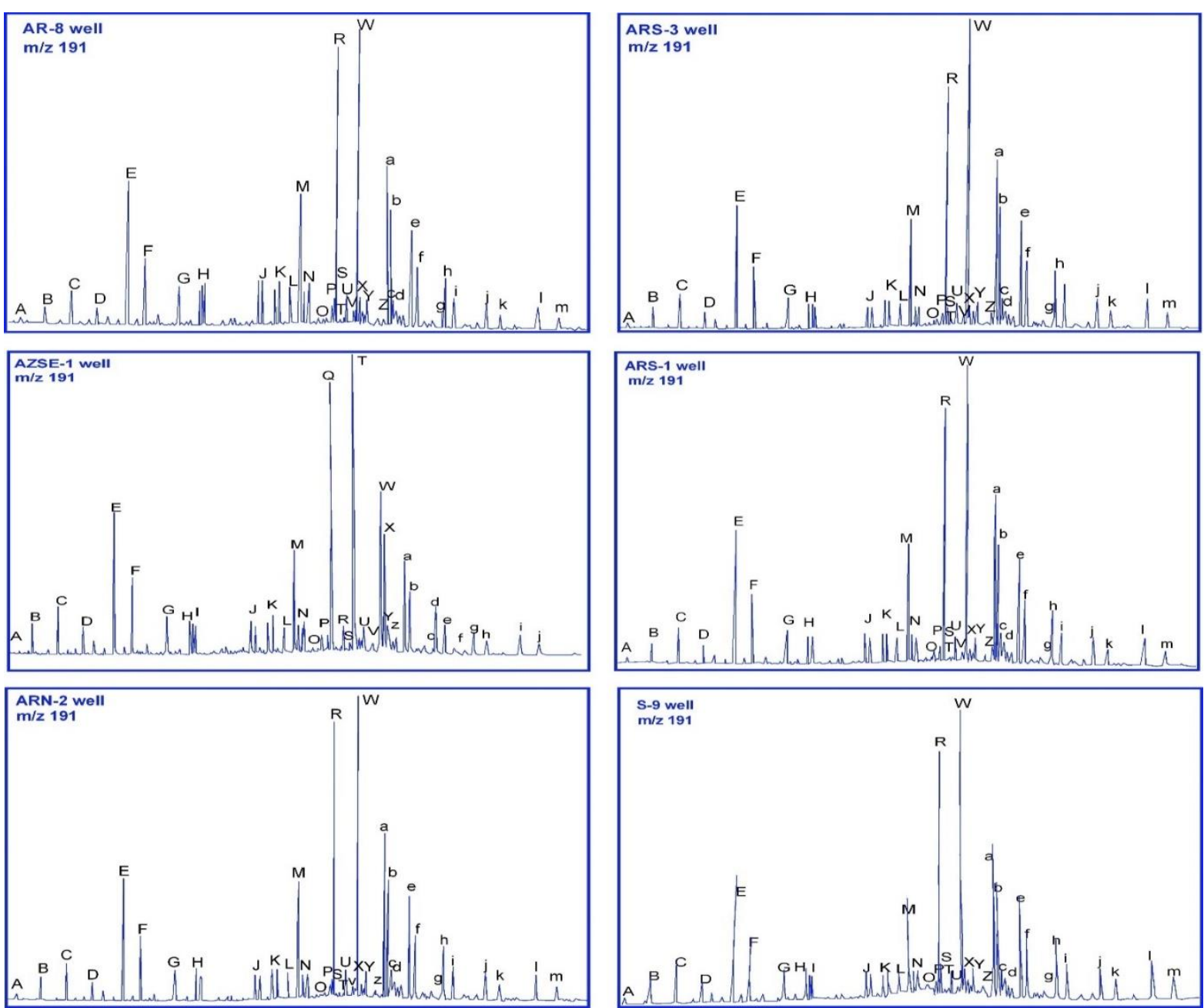

Figure 6 Triterpanes ( $\mathrm{m} / \mathrm{z191)}$ in ARAZ area.

A, $C_{19}$ Tricyclic; B, C 20 Tricyclic; C, C 21 Tricyclic; D, C 22 Tricyclic; E, C 23 Tricyclic; F, C 24 Tricyclic; G, $C_{25}$ Tricyclic-1\&2; H, C 24

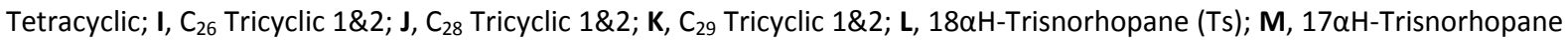

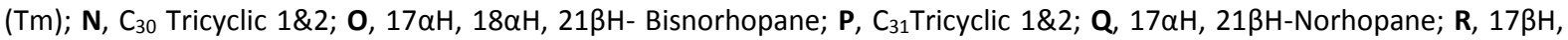

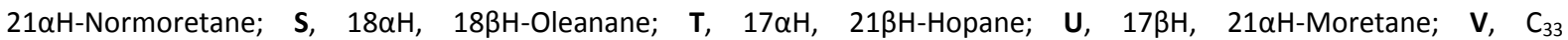
Tricyclic1\&2;W,17 $\alpha \mathrm{H}, 21 \beta \mathrm{H}-$ Homohopane(22S);X,17 $\alpha \mathrm{H}, 21 \beta \mathrm{H}$-Homohopane (22R); Y, Gammacerane; Z, C 34 Tricyclic 1\&2; a,

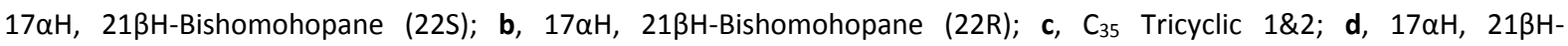

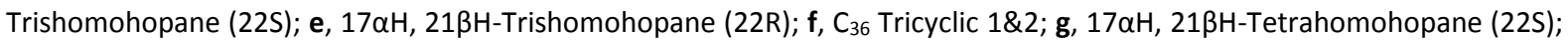

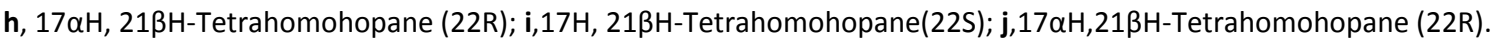

The oils show little higher land plant and high algal/bacterial derived organic material indicated by triterpanes distributions showing a high Hopane content (64-72\%), low C19 and C20 Tricyclics / C23 Tricyclics ratios (0.20-0.27) and low C27, C28 \& C29 sterane (Fig. 10). The Hopane/steranes ratio is low ranging from 1.5 to 3.1 suggesting that the algal source contribution is more than the microbial contribution, while the bacterial contribution is greater in the oils of wells ARS-3 and ARN. The organic facies deposited under marine conditions indicated by the $\mathrm{C} 30$ sterane (5\%) and the high amount of C31-C35 Hopanes (45-50\%) and the relatively high C35/C34 extended Hopane ratio (0.99 - 1.12) suggesting that the source rocks are carbonates.

\section{The impact of oils characterization on hydrocarbon} migration

The oils of the ARAZ area are low-moderately mature, sour derived from pre-Miocene marine, carbonate rich sources of Duwi and Thebes limestones. Rohrback (1983 [52]) stated that the oils of the Gulf of Suez approximately have the same origin and the variations in chemical composition attributed to the level of maturity. API gravity, asphaltene and NSO contents of the oils approximately are similar, while AZSE-1 and ARN-2 oils have higher asphaltene content increasing the viscosity of both wells than the other wells. The maturity of oils is relatively similar and with the depth, the oils are progressively heavier and richer in asphaltene fraction (Fig. 11), which consequently is affecting on the hydrocarbon migration. The oils rich in NSO and asphaltene fractions are heavy and migrate difficulty, while the oils rich in saturates and aromatics migrate more easily. The oils of northern AZSE-1 and ARN-2 wells are heavier than the other wells indicating low maturity level, deep reservoirs and short migration path (Fig. 12). 

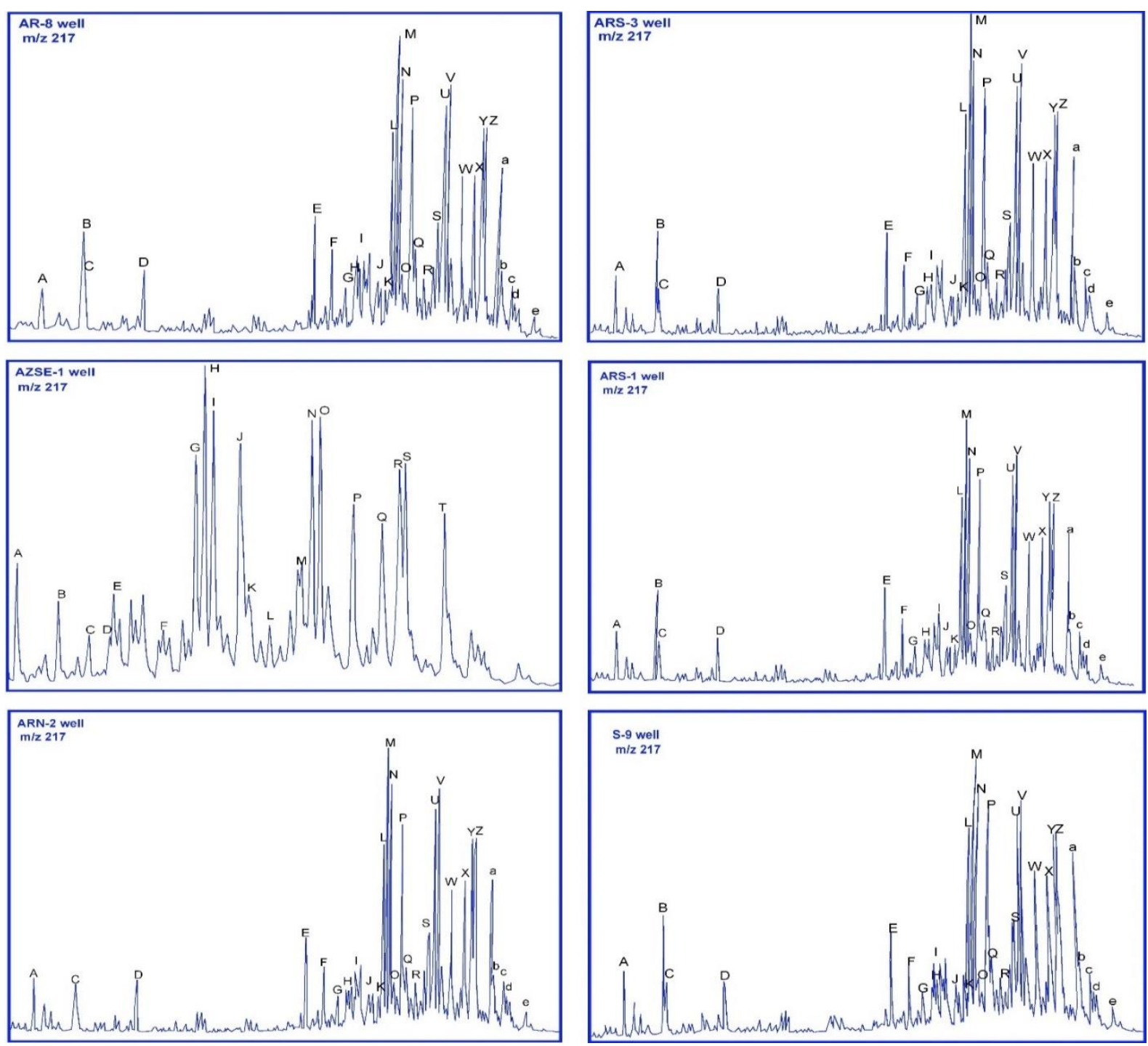

Figure 7 Steranes ( $\mathrm{m} / \mathrm{z} 217)$ in ARAZ area.

A, C and D, $\beta \alpha$ diasteranes (20S); B \& D, C27 $\beta \alpha$ diasteranes (20R); E, C28 $\beta \alpha$ diasteranes (20S); F, C28 $\beta \alpha$ diasteranes (20R); G, C27 $\alpha \alpha \alpha$ (20S) + C28 $\alpha \beta$ dia- (20S); H, C27 $\alpha \alpha \alpha$ (20R) + C29 $\alpha \beta$ dia- (20S); I, C27 $\alpha \alpha \alpha$ (20S) + C28 $\alpha \beta$ dia- (20R); J, C27 sterane (20R); K, C29 $\beta \alpha$ diasterane (20S); L, C29 diasterane (20S); M, C28 $\alpha \alpha \alpha$ sterane (20S); N, C28 $\alpha \beta \beta$ sterane (20R); O, C28 $\alpha \beta \beta$ sterane (20S); P, C28 $\alpha \alpha \alpha$ sterane (20R); Q, C29 $\alpha \alpha \alpha$ sterane (20S); R, C29 $\alpha \beta \beta$ sterane (20R); S, C29 $\alpha \beta \beta$ sterane (20S); T, C29 $\alpha \alpha \alpha$ sterane (20R).

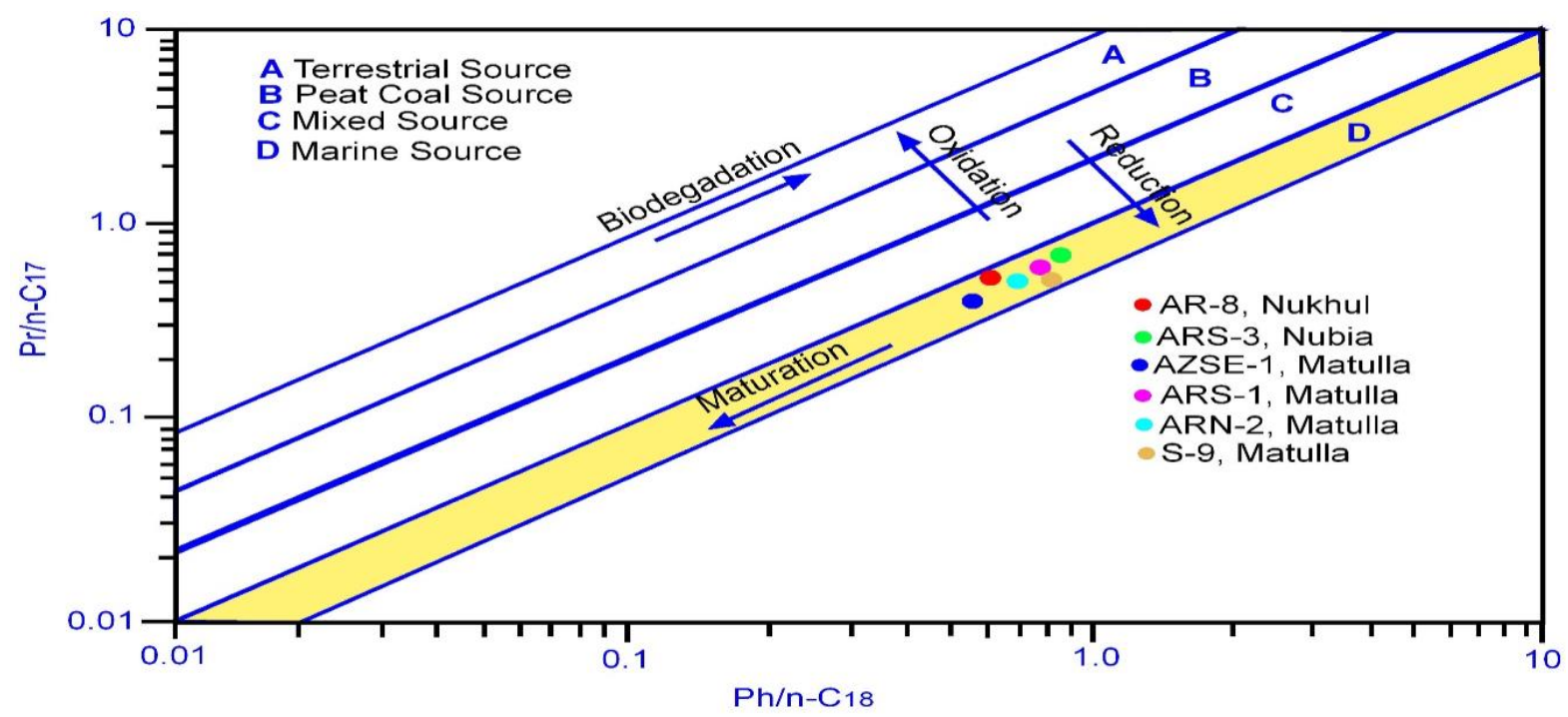

Figure 8 Plot of $\mathrm{Pr} / \mathrm{n}-\mathrm{C} 17$ versus $\mathrm{Ph} / \mathrm{n}-\mathrm{C} 18$ in ARAZ area. 


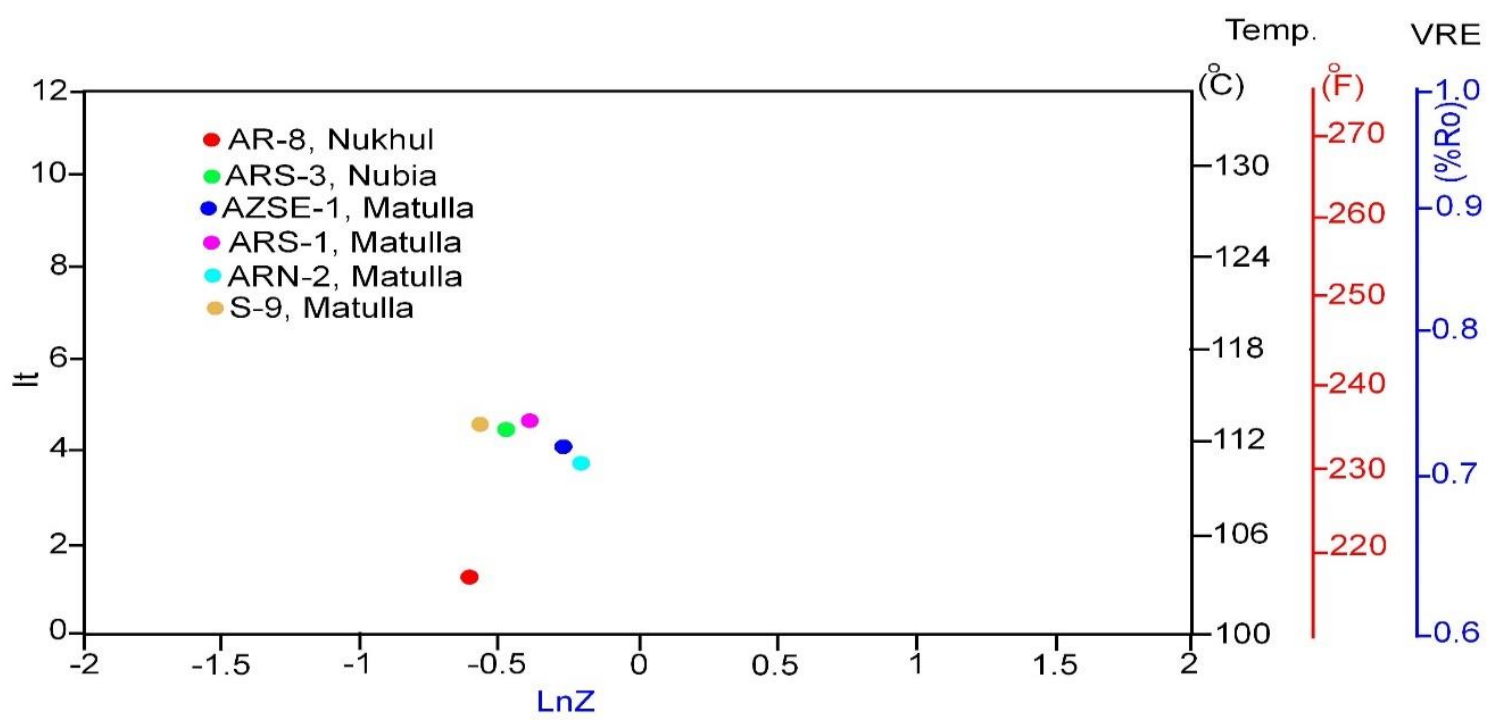

Figure 9 Expulsion temperature based on $\mathrm{C}_{7}$ components.

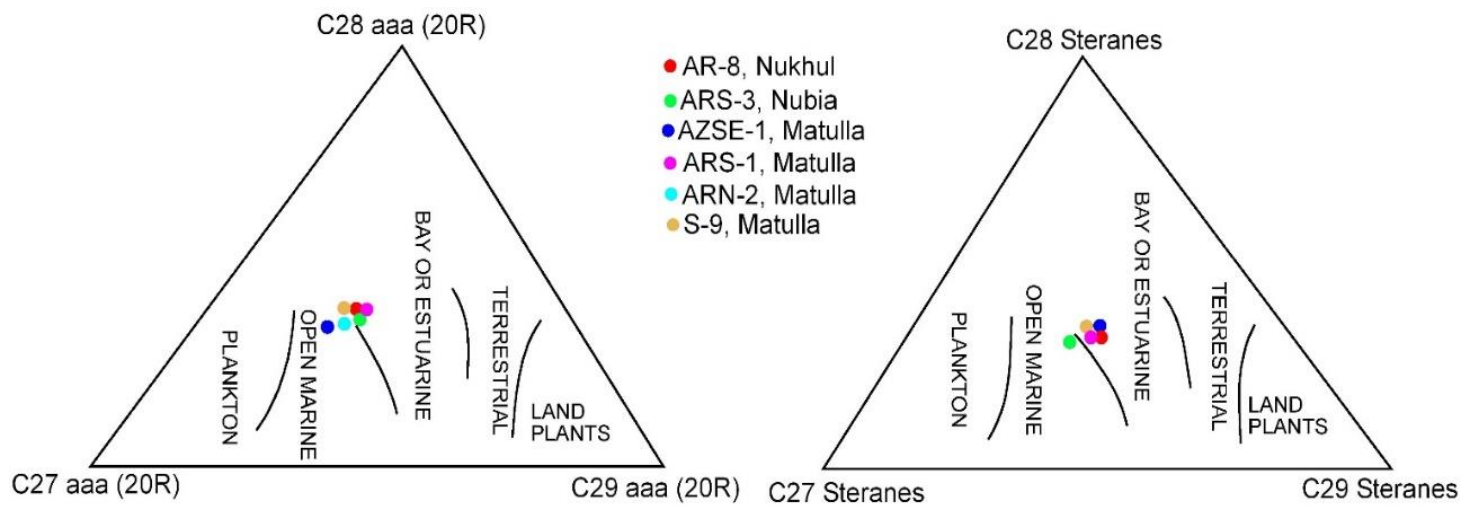

Figure 10 Ternary plots showing relative abundance of C27, C28 and C29 steranes.
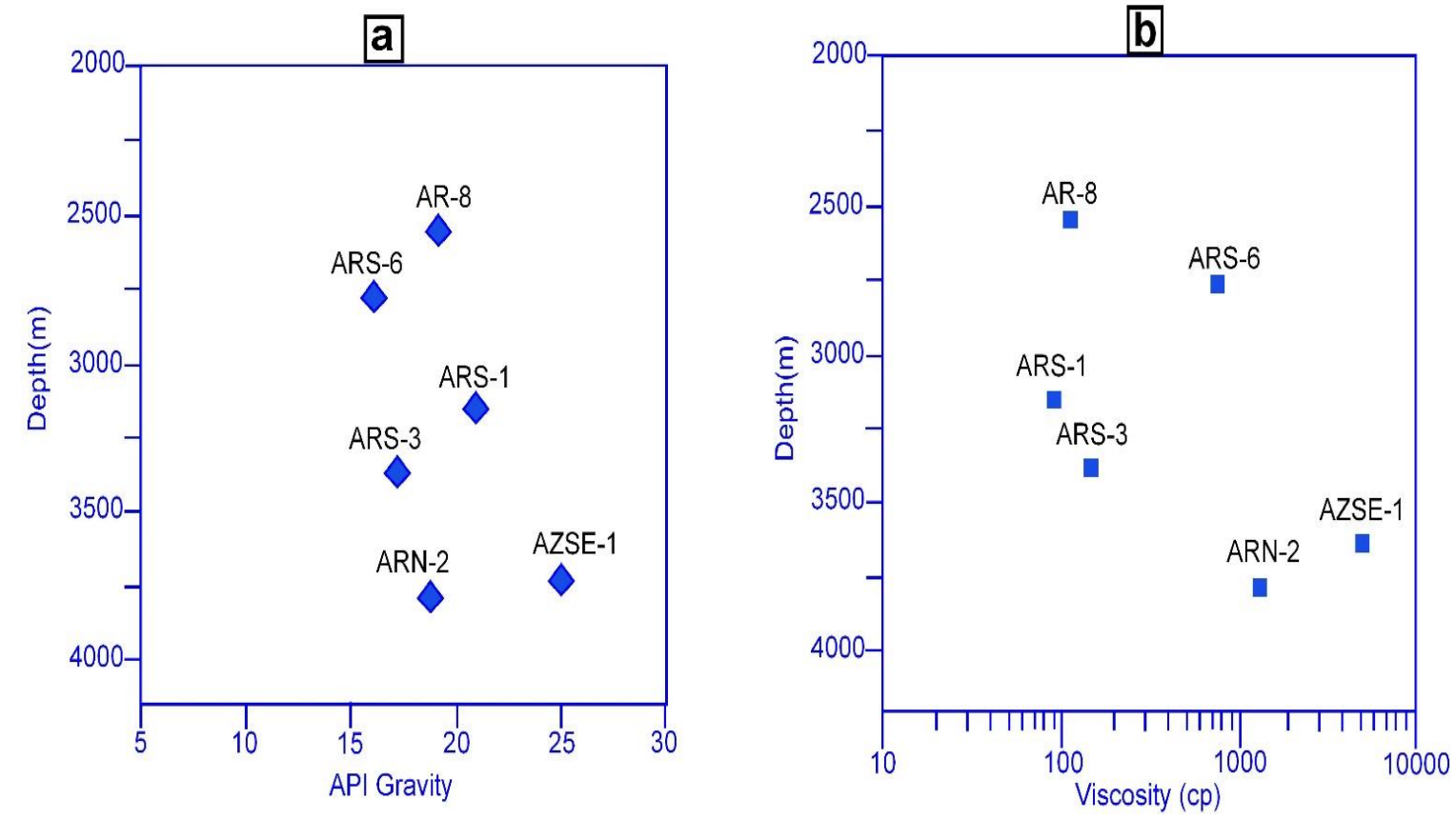

Figure 11 API gravity versus depth (a) and viscosity versus depth (b). 


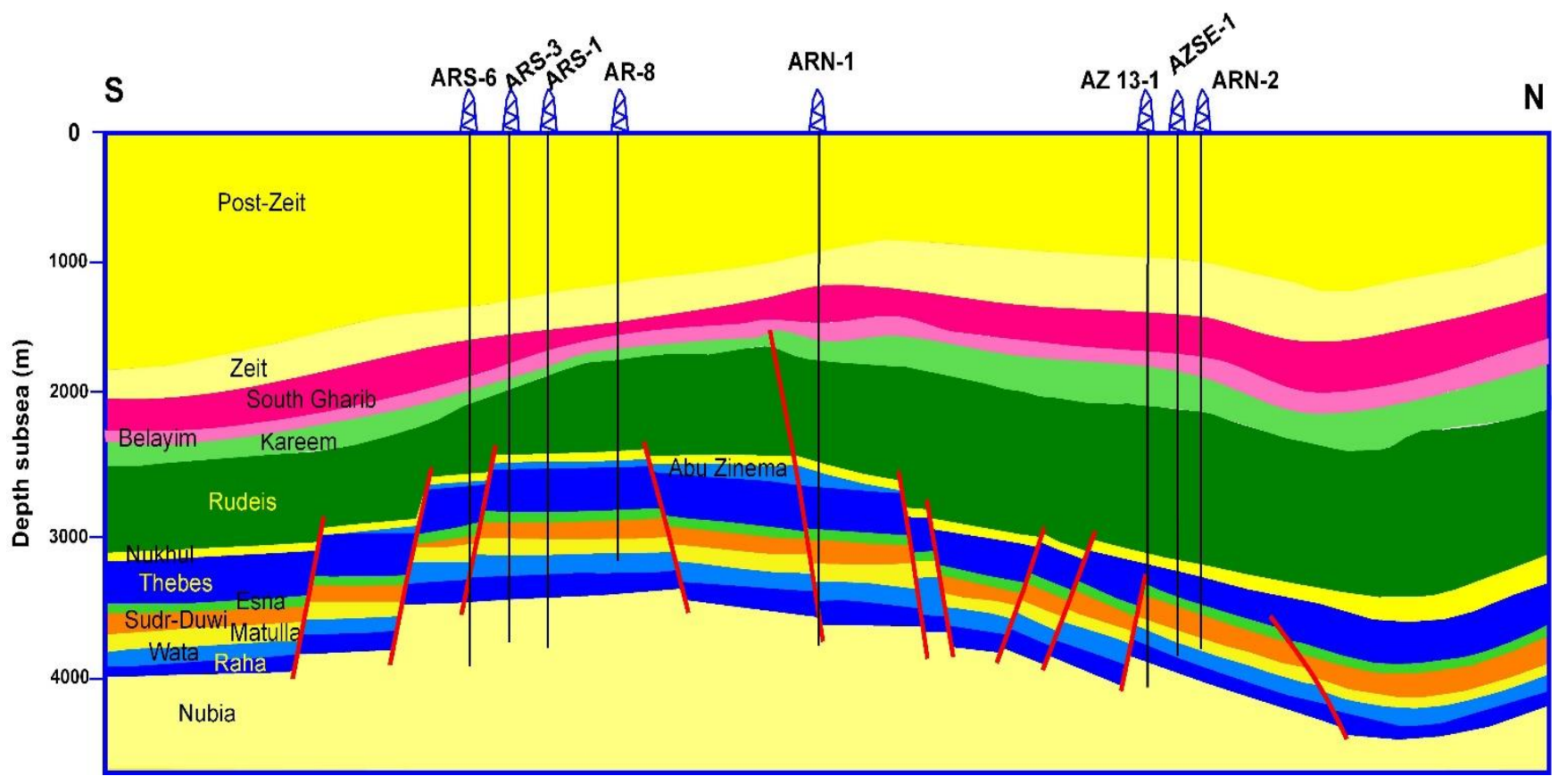

Figure 12 Regional geological cross-section through Abu Rudeis-Abu Zenima area.

\section{Conclusions}

In ARAZ area, the geochemical and biomarker data are available for seven wells AZSE-1, ARN-2, AR-8, ARS-1, ARS3, ARS- 6 and S-9. ARS- 6 and AZSE- 1 wells are similar in the geochemical analysis, and AZSE-1 well selected to represent both wells. Seven oils collected from different reservoir intervals such Nubia-A, Matulla, Thebes and Nukhul reservoirs. The bulk composition of the most oils characterized by a medium saturates and aromatics (54.773.8 wt \%), relatively high NSO \&asphaltene contents (24.5 -35.1 wt \%), a heavy API gravity (API > $12.8^{\circ}$ and $<25.3^{\circ}$ ) and a relatively high sulfur content. The variations in bulk oils composition not primarily related to the API gravity and sulfur contents, but attributed to the thermal maturity. The oils of ARAZ area generated from marine organic matter with little terrestrial materials indicated by the stable carbon isotopes of saturates and aromatics in oil of well S-9. The biomarker ratios of terpanes and steranes indicate algal marine organic materials with little land plants. The Pristane/Phytane ( $\mathrm{Pr} / \mathrm{Ph})$ ratio is low $(<1)$ suggesting a marine organic material deposited under moderate reducing depositional environments. The generation stage of the oils reached the peak-oil indicated by the sterane isomerization ratio (20S\% C29) is less than $55 \%$. The oils generated from different source rocks with different thermal maturity levels indicated by vanadium / nickel ratio. The organic facies are carbonates deposited under marine conditions indicated by the C30 sterane (5\%) and the high amount of C31-C35 Hopanes (45-50\%) and the relatively high C35/C34 extended Hopane ratio (0.991.12).

\section{Funding sources}

This research received no external funding.

\section{Conflicts of interest}

There are no conflicts to declare.

\section{Acknowledgment}

The author would like to express gratitude to the Egyptian Petroleum Corporation (EGPC) and Petrobel Company for providing the data for this study.

\section{References}

[1] A.S. Alsharhan and M.G. Salah, Hydrocarbon Habitat in the Gulf of Suez Rift Basin : Abstracts, AAPG Bulletin, vol. 81 (1997), doi: 10.1306/3b05c794-172a-11d78645000102c1865d.

[2] H. E. Wever. A common source rock for Egyptian and Saudi hydrocarbons in the Red Sea: Discussion. American\Association of Petroleum Geologists Bulletin, 83(5), 802-804, (1999).

[3] H. E. Wever, Petroleum and source rock characterization based on C7 plot results: Examples from Egypt. American Association of Petroleum Geologists Bulletin, 84 (7), 1041-1054, (2000).

[4] A.S. Alsharhan, Petroleum geology and potential hydrocarbon plays in the Gulf of Suez rift basin, Egypt. AAPG Bulletin, 87 (1), 143-180, (2003).

[5] M. A. Younes and R.P. Philp, Source rock characterization based on biological marker distributions of crude oils in the southern Gulf of Suez. Egypt. Journal of Petroleum Geology, 28(3), 301-317, (2005).

[6] M. M. El Nady and N. S. Mohamed, Source rock evaluation for hydrocarbon generation in Halal oilfield, southern Gulf of Suez, Egypt, Egyptian Journal of Petroleum. vol. 
25, no. 3 (2016) 383-389, doi: 10.1016/j.ejpe.2015.09.003.

[7] N.S. Mohamed, M. M. El Nady, Potentiality and timing of generation of Kareem and Rudeis formations, Central Gulf of Suez, Petroleum Science and Technology 37(8): 925-933,

(2019). https://doi.org./10.1080/10916466.2018.1558245.

[8] M.M. El Nady, N.S. Mohamed and A. N. Shahin, SourceRock Potential of Miocene-Paleozeoic Sediments in GH376 Oilfield, South Gulf of Suez, Egypt. J. Energy Sources, Part A: Recovery, Utilization, and Environmental Effects, $38 \quad$ (1): 100-109

(2016) doi.10.1080/15567036.2012.754518.

[9] M.A. Younes, M. M. Afife \& M. M. El Nady “Geochemical characteristics of crude oils dependent specific and biomarker distributions in the central-southern Gulf of Suez, Egypt, Energy Sources, Part A: Recovery, Utilization, and Environmental Effects, 39(2): 191-200 (2017), doi.10.1080/15567036.2016.1208306.

[10] N. S. Mohamed, and M. M. El Nady "Utilizing the Rockeval pyrolysis and biomarkers parameters to characterize the organic matters of selected wells in the Central Gulf of Suez, Egypt. J. Energy Sources, Part A: Recovery, Utilization, and Environmental Effects, 38(21): 3158-3166

(2016), doi.10.1080/15567036.2016.1141270.

[11] W. Sh. El Diasty, S. Y. El Beialy, A. R. Mostafa, A. A. Abo Ghonaim, and K. E. Peters, Chemometric Differentiation of Oil Families and Their Potential Source Rocks in the Gulf of Suez, Natural Resources Research, Vol. 29, No. 3 (2020), https://doi.org/10.1007/s11053-019-09569-3.

[12] Kh. G. Elmaadawy, H. A. Elbassiouny and S. M. Raslan, Thermal Maturity and Hydrocarbon Generation Modelling for the Lower Rudeis Source Rock and Petroleum System Analysis in Garra Area, South Gulf of Suez, Egypt, Journal of Petroleum and Mining Engineering, Vol, 23, (1), 62-78, (2021), DOI: 10.21608/jpme.2021.62686.1071.

[13] Z. Garfunkel, Y. Bartov, The tectonics of the Suez rift. Geol. Surv. Isr. Bull 71, I-44, (1977).

[14] T.L. Patton, A.R. Moustafa, R.A. Nelson, and S.A. Abdine, Tectonic evolution and structural setting of the Suez rift. In: London SM (ed) Interior rift basins, American Association of Petroleum Geologists Memoir 59, 7-55, (1994).

[15] A. R. Moustafa, Internal structure and deformation of an accommodation zone in the northern part of the Suez rift, Journal of Structural Geology, vol. 18, no. 1, (1996) 93-107, doi: 10.1016/0191-8141(95)00078-r.

[16] A. I. Younes and K. R. McClay Development of accommodation zones in the Gulf of Suez-Red Sea rift, Egypt. American Association of Petroleum Geologists Bulletin, 86(6), 1003-1026, (2002).

[17] B. Colletta, P. Le Quellec, J. Letouzey, and I. Moretti, Longitudinal evolution of the Suez rift structure (Egypt), Tectonophysics, vol. 153, no. 1-4 (1988) 221-233, doi: 10.1016/0040-1951(88)90017-0.

[18] W. Bosworth, A high-strain rift model for the southern Gulf of Suez (Egypt). In J. J. Lambaise (Ed.), Hydrocarbon habitat in rift basins. London: Geological Society of London, Special Publication, Vol. 80, pp. 75-112, (1995).
[19] W. Bosworth, Geological evolution of the Red Sea: Historical background, review, and synthesis. In N. M. A. Rasul \& I. C. F. Stewart (Eds.), The Red Sea (pp. 45-78). Berlin: Springer, (2015).

[20] W. Bosworth and S. Durocher, Present-day stress fields of the Gulf of Suez (Egypt) based on exploratory well data: Non-uniform regional extension and its relation to inherited structures and local plate motion. Journal of African Earth Sciences, 136, 136-147, (2017).

[21] W. Bosworth, P. Crevello, R. D. Winn \& J. Steinmetz, Structure, sedimentation, and basin dynamics during rifting of the Gulf of Suez and northwestern Red Sea. In B. H. Purser \& D. W. J. Bosence (Eds.), Sedimentation and tectonics of rift basins: Red Sea-Gulf of Aden (pp. 77-96). London: Chapman and Hall, (1998).

[22] S. M. Khalil and K. R. McClay, Tectonic evolution of the NW Red Sea-Gulf of Suez rift system. In R. C. L. Wilson, R. B. Whitmarsh, B. Taylor, \& N. Froitzheim (Eds.), Nonvolcanic rifting of continental margins: A comparison of evidence from land and sea (Vol. 187, pp. 453-473). London: Geological Society of London, Special Publication, (2001).

[23] J. A. M. M. Peijs, T. G. Bevan, and J. T. Piombino, The Gulf of Suez rift basin," Regional Geology and Tectonics: Phanerozoic Rift Systems and Sedimentary Basins. Elsevier, 164-194, (2012), doi: 10.1016/b978-0-44456356-9.00007-9.

[24] E.H. Klitzsch, C.H. Squyres, Paleozoic and Mesozoic geological history of northeastern Africa based upon new interpretation of Nubian strata. Am. Assoc. Pet. Geol. Bull. 74, 1203-1261, (1990).

[25] E.H. Klitzsch, Paleozoic. In: Said, R. (Ed.), the Geology of Egypt. Balkema, Rotterdam, pp. 393-406, (1990).

[26] M. Darwish and A.M. El-Araby, Petrography and diagenetic aspects of some siliciclastic hydrocarbon reservoirs in relation to the rifting of the Gulf of Suez: Geological Society of Egypt, Special Publication, 1155187, (1993).

[27] Egyptian General Petroleum Corporation (EGPC). Oligocene and Miocene rock-stratigraphy of the Gulf of Suez region, report of the Stratigraphic Committee: Egyptian General Petroleum Corporation, 142 pp (1964).

[28] B. Issawi, Nubia Sandstone: Type Section: Geological Notes, AAPG Bulletin, vol. 57, (1973), doi: 10.1306/819a431c-16c5-11d7-8645000102c1865d.

[29] D.J. Webster, Post Eocene stratigraphy of the Suez rift, Egypt: 6th Egyptian general petroleum corporation. In: Petroleum Exploration and Production Conference, vol. 1. pp. 76-189, (1982).

[30] B.W Sellwood and R.E. Netherwood, Facies evolution in the Gulf of Suez area: sedimentation history as an indicator of rift initiation and development. Modern Geol., 9 (1984) 43-69.

[31] K. R. McClay, G. J. Nichols, S. M. Khalil, M. Darwish and W. Bosworth, Extensional tectonics and sedimentation, eastern Gulf of Suez, Egypt. In B. H. Purser \& D. W. J. Bosence (Eds.), Sedimentation and tectonics in rift basins: Red Sea-Gulf of Aden (pp. 211-238), London: Chapman Hall, (1998).

[32] R. W. Scott and F. M. Govean, Early depositional history of a rift basin: Miocene in Western Sinai, Palaeogeography, Palaeoclimatology, Palaeoecology, 
vol. 52, no. $1-2,143-158$, (1985) doi: 10.1016/00310182(85)90035-5.

[33] J. L. Smale, R. C. Thunell, and S. Schamel, Sedimentological evidence for early Miocene fault reactivation in the Gulf of Suez, Geology, vol. 16, no. 2, p. 113, (1988), doi: 10.1130/00917613(1988)016<0113:sefemf>2.3.co;2.

[34] J. M. Rouchy, D. Noël, A. M. A. Wali, and M. A. M. Aref, Evaporitic and biosiliceous cyclic sedimentation in the Miocene of the Gulf of Suez-Depositional and diagenetic aspects, Sedimentary Geology, vol. 94, no. 34 277-297, (1995), doi: 10.1016/0037-0738(94)00095-c.

[35] M. Richardson, M.A. Arthur, The Gulf of Suez-northern Red Sea neogene rift: a quantitative basin analysis. Mar. Pet. Geol. 5, 247-270, (1988).

[36] S. Rohais, A. Barrois, B. Colletta, and I. Moretti, Pre-salt to salt stratigraphic architecture in a rift basin: insights from a basin-scale study of the Gulf of Suez (Egypt), Arabian Journal of Geosciences, vol. 9, no. 4 (2016), doi: 10.1007/s12517-016-2327-8.

[37] V. Robinson and M. Engel, Characterization of the source horizons within the Late Cretaceous transgressive sequence of Egypt. In B. Katz \& L. Pratt (Eds.), Source rocks in a sequence stratigraphic framework (pp. 101117). Tulsa: American Association of Petroleum Geologists, Studies in Geology, (1993).

[38] W. Sh. El Diasty and K. E. Peters, Genetic classification of oil families in the central and southern sectors of the Gulf of Suez, Egypt. Journal of Petroleum Geology, 37, 105126, (2014).

[39] M. El-Shafeiy, D. Birgel, A. El-Kammar, A. El-Barkooky, M. Wagreich and $S$. Tahoun, Integrated palaeoenvironmental proxies of the Campanian to Danian organic rich Quseir section, Egypt. Marine and Petroleum Geology, 86, 771-786, (2017).

[40] K. F. M. Thompson, Fractionated aromatic petroleums and the generation of gas-condensates, Organic Geochemistry, 11, 573-590, (1987).

[41] J. P. Clark and R. P. Philp, Geochemical characterization of evaporite and carbonate depositional environments and correlation of associated crude oils in the Black Creek Basin, Alberta. Bulletin of Canadian Petroleum Geology, 37, 401-416, (1989).
[42] E. A. Subroto, R. Alexander and R. I. Kagi, 30Norhopanes: their occurrence in sediments and crude oils. Chemical Geology, 93, 179-192, (1991).

[43] A.S. Alsharhan and M.G. Salah, Hydrocarbon Habitat in the Gulf of Suez Rift Basin : Abstracts, AAPG Bulletin, vol. 81, (1997), doi: 10.1306/3b05c794-172a-11d78645000102c1865d.

[44] Z. Sofer, Stable carbon isotope composition of crude oils: Application to source depositional environments and petroleum alteration. American Association of Petroleum Geologists Bulletin, 68(1), 31-49, (1984).

[45] J. W. Collister and D. A. Wavrek, $\delta 13 C$ compositions of saturate and aromatic fractions of lacustrine oils and bitumens: Evidence for water column stratification. Organic Geochemistry, 24, 913-920, (1996).

[46] J. M. Hunt, Petroleum geochemistry and geology ( $p$. 743). New York: Freeman and Company, (1996).

[47] K. E. Peters, C. C.Walters and J. M. Moldowan, The biomarker guide (2nd ed., p. 1155). Cambridge: Cambridge University Press, (2005).

[48] A. R. Mostafa, Organic geochemistry of source rocks and related crude oils in the Gulf of Suez. Egypt. Berliner Geowissenschaftliche Abhandlungen, A, 147, 163, (1993).

[49] J. Connan and A. M. Cassou, Properties of gases and petroleum liquids derived from terrestrial kerogen at various maturation levels. Geochimica et Cosmochimica Acta, 44(1), 1-23 (1980).

[50] K. E. Peters, T. H. Fraser, W. Amris, B. Rustanto and E. Hermanto, Geochemistry of crude oils from Eastern Indonesia. American Association of Petroleum Geologists Bulletin, 83, 1927-1942 (1999).

[51] J. M. Moldowan, P. Sundararaman and M. Schoell Sensitivity of biomarker properties to depositional environment and/or source input in the Lower Toarcian of SW-Germany. Organic Geochemistry, 10, 915-926, (1986).

[52] B.G. Rohrback, Crude oil geochemistry of the Gulf of Suez. In M. Bjorøy, C. Albrecht, C. Cornford, et al., (Eds.), (1983), Advances in organic geochemistry, pp. 39-48, (1981), Chichester: Wiley and Sons, Ltd. 